\title{
閉鎖性海域における水産養殖からの負荷を考慮した環境影響評価に関する研究 A STUDY ON ENVIRONMENTAL IMPACT ASSESSMENT CONSIDERING LOADS FROM AQUACULTURE IN THE SEMI-ENCLOSED BAY
}

\author{
安岡かおり*, 末永慶寛 ${ }^{* *}$, 松島 学***, 増田光一 $* * * *$ \\ Kaori YASUOKA, Yoshihiro SUENAGA, Manabu MATSUSHIMA \\ and Kouichi MASUDA
}

\begin{abstract}
Many kinds of marine aquaculture have been conducted in the semi-enclosed bay. In Sido-bay where located north-eastern area of Kagawa Prefecture could produce marine aquaculture productions to supply the population demands. On the other hand, the feeding rate of fish farming is approximately 13,000 tones by year, which highest feed in the summer season. Therefore, the pollution from many floating aquaculture facilities can affect the environment via fecal waste and excess feed settles. After the filed research, it was found the tidal current, bottom topography and dissolved oxygen consumption rate by sediment are very important factors to evaluate the carrying capacity of aquaculture grounds. The authors proposed more quantitative evaluation technique for that capacity using the numerical model taking the effect from the oxygen consumption by the fish in the aquaculture cage and bottom sediment.
\end{abstract}

Keywords: semi-enclosed bay, aquaculture, tidal current, numerical model, dissolved oxygen

閉鎖性海域, 養殖, 潮流, 数值モデル, 溶存酸素

\section{1. 粕言}

東京湾，大阪湾，瀬戸内海を代表とする閉鎖性海域は，古くから 水産業が盛んに行われてきた。近年，これらの海域の高い生物生産 力に着目し, 海洋空間の有効利用のための様々な施策が講じられて いる。具体的には, レクリエーション施設として, 釣り公園, 義殖 施設，生物を利用した保養施設（例えば生物セラピー）等の建設で ある。これらの建築物は, 同時に水産資源生産力向上を期待するも のである。しかし，それらの施策の多くは，沿岸都市部の急激な経 済活動の発展に伴い, 富栄養化の進行等による水域環境の悪化に悩 まされている。富栄養化は生態系内の生産, 消費, 分解のバランス を崩し, 水質污濁や底層水貧酸素化, 更には赤潮や青潮等の現象を 招く原因となっている。解決策としては，沿岸域の開発における代 表的な環境影響評価手法の一つとして，沿岸生態系モデルによる環 境予測がある。これは, 閉鎖性内湾を対象とした海域の物理過程と 生物過程を物質の動態解析により，環境影響を予測するというもの である。これまで，沿岸生態系モデルによる環境予測は様々な海域 を対象として数多く報告されてきており，その多くは定性的に観測 結果を再現しているが，定量的な評価という面では厳密な評価がそ れほど行われていないというのが現状である。田中らににより，富 栄養化などが原因で赤潮が頻発し, 毎年のように海域環境の悪化が
哚刻化している香川県志度湾（図-1）を対象として, 沿岸生態系モ デルによる環境影響評価が行われているが，厳密かつ定量的評価を 行うまでには至っていない。水産養殖からの負荷とは，主に養殖筏 からの投餌, 魚類の排蕒のことで, これらは養殖密度と密接な関保 があり, 結果的に底泥による酸素消費を促進させ, 貧酸素状態を形 成させる。それらが水質の悪化，魚類の生存や成長を阻害するとい った悪循環が生まれる。当然のことながら, 魚類の呼吸による酸素 消費も，海域の溶存酸素量減少など生物生息環境に強い影響を与え るものと考えられる。沿岸生態系にとって，水産養殖や生物を飼育 している保養施設からの負荷は重要な要素であることから，これを 数值モデルに考慮することで, より高精度な海域特性の再現かつ定 量的な環境影響評価が可能であると考える。

本研究では，水産養殖からの負荷に伴う溶存酸素量の収支に着目 し，それらを考慮した数值モデルにより，養殖漁場における環境変 化および養殖密度を指標とした環境容量について定量的な評価を 行うことを目的とした。既存の研究 1), 2),3)では，志度湾に関する厳 密な酸素消費速度を取り扱った研究は行われておらず，対象海域全 域に一定值で与えていた消費速度に対し，本研究では，養殖の影響 を精度良く計算するために特性の違う場所毎の值を与えた。具体的 には, 数值モデルの溶存酸素量の収支式中の生物反応項に, 魚類の

\footnotetext{
* 香川大学大学院工学研究科 博士後期課程 $\cdot$ 工修

** 香川大学工学部安全システム建設工学科 助教授.工博

$* * *$ 香川大学工学部安全システム建設工学科教授・工博

**** 日本大学理工学部海洋建築工学科 教授. 工博
}

Graduate School Student, Dept. of Eng., Kagawa Univ., M.S.

Assoc. Prof.. Faculty of Eng., Kagawa Univ., Dr. Eng.

Prof., Faculty of Eng., Kagawa Univ., Dr. Eng.

Prof., Dept. of Oceanic Arch. \& Eng., Nihon Univ., Dr. Eng. 
酸素消費速度について志度湾の養殖業の大半を占める八マチを代 表種と選定した飼育実験を行い, 魚類による酸素消費速度を適用し た。また，生物反応項中の底泥による酸素消費速度 2)に関しては， 数值モデル対象海域の底泥をサンプリングし, 海水をろ過した後, 不擋乱コア法を用いて底泥による酸素消費速度を求めて数值モデ ルに適用した。

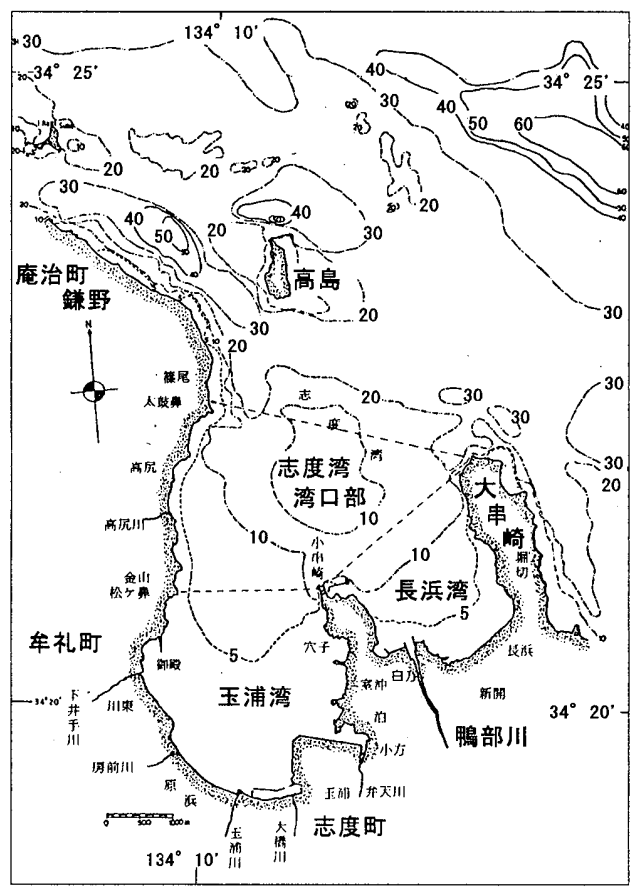

図 1 志度湾

\section{2. 数値モデル}

志度湾のような閉鎖性海域では，物理的過程と共に生物的過程が 重要となってくるため, Eco-Hydrodynamics (生態一流体力学) と呼 ばれる, 流体力学系と生態系の相互作用を定式化した体系を取り扱 う。

\section{2-1. 基礎方程式}

潮流の計算モデルには，3 次元の鉛直多層（マルチレベル）モデ ルを用いる。マルチレベルモデルの基礎式は, 運動量, 質量, 熱量, 塩素量の保存式と状態方程式を鉛直方向に積分することにより導 かれる 4), 5)。

数值シミュレーションでは，これらの基礎式を，空間において中 央差分法により離散化する。ただし，移流項だけは，上流差分法を 用いる。マルチレベルモデルにおける座標系を図 2-1に示す。また， 計算にはスタッガードメッシュを用いる。各物理量の配置は，格子 中央に水深, 水温, 塩素量, 密度を置き, 格子線上に流速を置く。 水平方向, 鉛直方向における各パラメータの配置をそれぞれ, 図 2-2, 図 2-3 に示す。また，用いる数值モデルの基礎方程式を，(1)〜 (6) 式に示す。

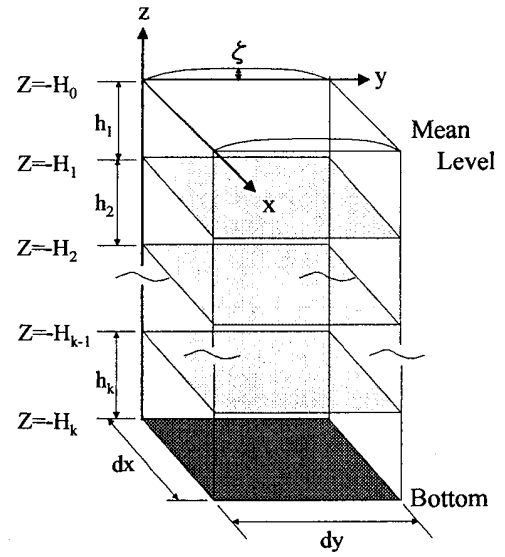

図 2-1 座標系

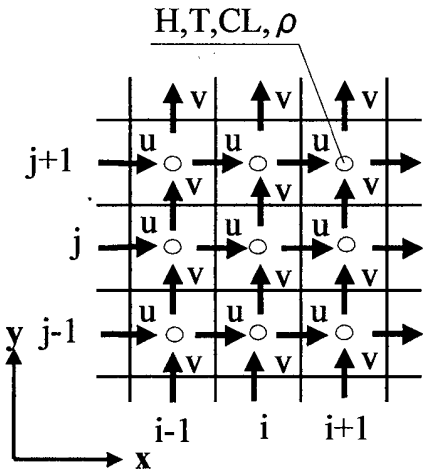

図 2-2 パラメータ配置（水平方向）

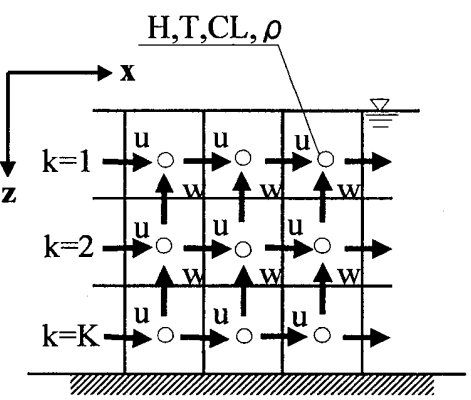

図 2-3 パラメータ配置（鉛直方向）

（1） $\mathrm{x}$ 方向の運動方程式

$$
\begin{aligned}
& \frac{\partial u}{\partial t}+u \frac{\partial u}{\partial x}+v \frac{\partial u}{\partial y}+w \frac{\partial u}{\partial z} \\
& =f_{0} v-\frac{1}{\rho} \frac{\partial P_{0}}{\partial x}+N_{x} \frac{\partial^{2} u}{\partial x^{2}}+N_{y} \frac{\partial^{2} u}{\partial y^{2}}+N_{z} \frac{\partial^{2} u}{\partial z^{2}}
\end{aligned}
$$

（2）y 方向の運動方程式

$$
\begin{aligned}
& \frac{\partial v}{\partial t}+u \frac{\partial v}{\partial x}+v \frac{\partial v}{\partial y}+w \frac{\partial v}{\partial z} \\
& =-f_{0} u-\frac{1}{\rho} \frac{\partial P_{0}}{\partial y}+N_{x} \frac{\partial^{2} v}{\partial x^{2}}+N_{y} \frac{\partial^{2} v}{\partial y^{2}}+N_{z} \frac{\partial^{2} v}{\partial z^{2}}
\end{aligned}
$$

（3） $\mathrm{z}$ 方向の運動方程式

$$
-g-\frac{1}{\rho} \frac{\partial P_{0}}{\partial z}=0
$$

(4) 連続の式

$$
\frac{\partial u}{\partial x}+\frac{\partial v}{\partial y}+\frac{\partial w}{\partial z}=0
$$


（5）自由表面の式

$$
\frac{\partial \zeta}{\partial t}=-\frac{\partial}{\partial x}\left(\int_{-H}^{\zeta} u d z\right)-\frac{\partial}{\partial y}\left(\int_{H}^{\zeta} v d z\right)
$$

（6）熱収支・塩素量収支の式

$$
\begin{aligned}
& \frac{\partial T}{\partial t}=-\frac{\partial}{\partial x}(u \cdot T)-\frac{\partial}{\partial y}(v \cdot T)-\frac{\partial}{\partial z}(w \cdot T) \\
& +\frac{\partial}{\partial x}\left(k_{x} \cdot \frac{\partial T}{\partial x}\right)+\frac{\partial}{\partial y}\left(k_{y} \cdot \frac{\partial T}{\partial y}\right)+\frac{\partial}{\partial z}\left(k_{z} \cdot \frac{\partial T}{\partial z}\right)
\end{aligned}
$$

ここで, $x, y, z$ は平均海面上の一点を原点とする直交座標系の座標， $t$ は時間, $u, v, w$ はそれぞれ $x, y, z$ 方向の流速, $f_{0}$ はコリオリパラメー 夕, $g$ は重力加速度, $P_{0}$ は大気圧, $\rho$ は海水の密度, $N_{x}, N_{y}, N_{z}$ は $x, y, z$

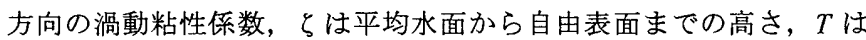
流体の質量温度（塩素量収支の場合は $S$ ) , $k_{x}, k_{y}, k_{z}$ は $x, y, z$ 方向の熱拡 散係数を表す。

\section{2-2. 沿岸生態系の基礎理論}

本研究では生態系の構成要素として, 植物プランクトン, 動物プ ランクトン, 栄養塩, デトリタス, そして水産養殖からの影響を考 慮する際に着目する溶存酸素量の収支まで検討する。各要素の基䃈 方程式を(7)式に示す。

$$
\begin{aligned}
& \frac{\partial}{\partial T}\left(h_{k}, B_{k}\right)=-\frac{\partial}{\partial X}\left(M_{k} \cdot B_{k}\right)-\frac{\partial}{\partial Y}\left(N_{k} \cdot B_{k}\right) \\
&(\text { 水平移流 }) \\
&-\left\{\left(w+w_{s}\right) B_{k}\right\}_{Z=-H_{k-1}}+\left\{\left(w+w_{s}\right) B_{k}\right\}_{Z=-H_{k}}
\end{aligned}
$$

（鉛直移流，沈降）

$$
+\left.\left(K_{z} \cdot \frac{\partial B}{\partial Z}\right)\right|_{Z=-H_{k-1}}-\left.\left(K_{z} \cdot \frac{\partial B}{\partial Z}\right)\right|_{Z=-H_{k}}
$$

(鉛直拡散)

$$
+\frac{\partial}{\partial X}\left(h_{k} \cdot K_{x} \cdot \frac{\partial B_{k}}{\partial X}\right)+\frac{\partial}{\partial Y}\left(h_{k} \cdot K_{y} \cdot \frac{\partial B_{k}}{\partial Y}\right)+h_{k} \cdot K_{x}
$$

（水平拡散）

ここで， $B_{k}$ は level $k(1 \sim K)$ における各コンパートメント（植物プ ランクトン・動物プランクトン・デトリタス・栄養塩・溶存酸素量) の現存量, $w$ は $Z$ 方向の流速成分, $w_{s}$ は物質の下層への沈降速度, $H$ は平均水面から海底までの深さ， $K_{x}, K_{y}, K_{z}$ はそれぞれ $x, y, z$ 方向の 抬散係数, $M_{k}$ は level $k$ での $x$ 方向線流量成分 $(=h \cdot u), N_{k}$ は level $k$ での $Y$ 方向線流量成分 $(=h \cdot v)$ とする。

\section{2-3. 溶存酸素量の収支}

今回の数値シミュレーションで水産養殖からの負荷を考慮する 際, 溶存酸素量の収支に着目し, 魚類による酸素消費 $\left(\gamma_{F}\right)$ と底泥に よる酸素消費 $\left(q_{B}\right)$ を生物反応項において取り扱う。以下に溶存酸 素量の基礎方程式を示す。

$$
\frac{\partial}{\partial t}\left(h_{k} \cdot X O_{2}\right)=-\frac{\partial}{\partial x}\left(M_{k} \cdot X O_{2}\right)-\frac{\partial}{\partial y}\left(N_{k} \cdot X O_{2}\right)
$$

(水平移流)

$$
-\left.\left\{\left(w+w_{s}\right) X O_{2}\right\}\right|_{z=-H_{k-1}}+\left.\left\{\left(w+w_{s}\right) X O_{2}\right\}\right|_{z=-H_{k}}
$$

（鉛直移流，沈降）

$+\frac{\partial}{\partial x}\left(h_{k} \cdot K_{x} \cdot \frac{\partial X O_{2}}{\partial x}\right)+\frac{\partial}{\partial y}\left(h_{k} \cdot K_{y} \cdot \frac{\partial X O_{2}}{\partial y}\right)$

(水平拡散)

$+\left.\left(K_{z} \cdot \frac{\partial X O_{2}}{\partial z}\right)\right|_{z=-H_{k-1}}-\left.\left(K_{z} \cdot \frac{\partial X O_{2}}{\partial z}\right)\right|_{z=-H_{k}}$

(鉛直拡散)

$+\gamma_{P} \cdot X P_{k}-\gamma_{Z} \cdot X Z_{k}$

$\left(X P_{k}\right.$ 生成) $\left(X Z_{k}\right.$ 消費 $)$

$-\gamma_{F}-q_{B}+q_{A}$

（魚類による消費）（底泥による分解）（溶入） ここで, $X O_{2}$ は溶存酸素量, $X P_{k}$ は植物プランクトン現存量, $X Z_{k}$ は動物プランクトン現存量, $\gamma P$ は, 植物プランクトンによる酸素 生成係数， $\gamma Z$ は動物プランクトンによる酸素消費係数， $\gamma F$ は魚 類による酸素消費速度， $q_{B}$ は底泥による酸素消費速度， $q_{A}$ は大気か らの酸素溶入量である。

\section{3. 流況に関する再現性の結果・考察}

志度湾の流況に関する再現性の検討は既存の研究で，湾奥から湾 央にかけて精度の良い再現が出来ていることが確認されている ${ }^{1)} 。$ しかし，この時は境界条件の取り方で，湾口部付近の流れを厳密に 再現するところまで至っていないと報告されている。そこで，この 流況に関する再現性の評価・検討では志度湾湾口部における流況に 特に着目し，計算領域を志度湾湾口部付近に存在し，流れに多大な 影響を及ぼす高島以北まで拡張して，評価・検討を行うこととした。

図 3 に計算領域を，表 1 に計算条件，表 2 に境界条件を示寸。計 算条件は，流動場の計算精度を向上させるため，既存の方法 ${ }^{1) ， 2) に ~}$ 比べ水平および鉛直方向の格子間隔を細かくした。各倸数は，既存

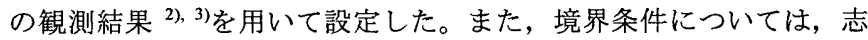
度湾東西の湾口にて潮位観測を行った結果を基に決定した。なお， 図中の A,B,C,D は志度湾の主な養殖エリア, St.1〜St.4 は潮流観測地 点を表す。

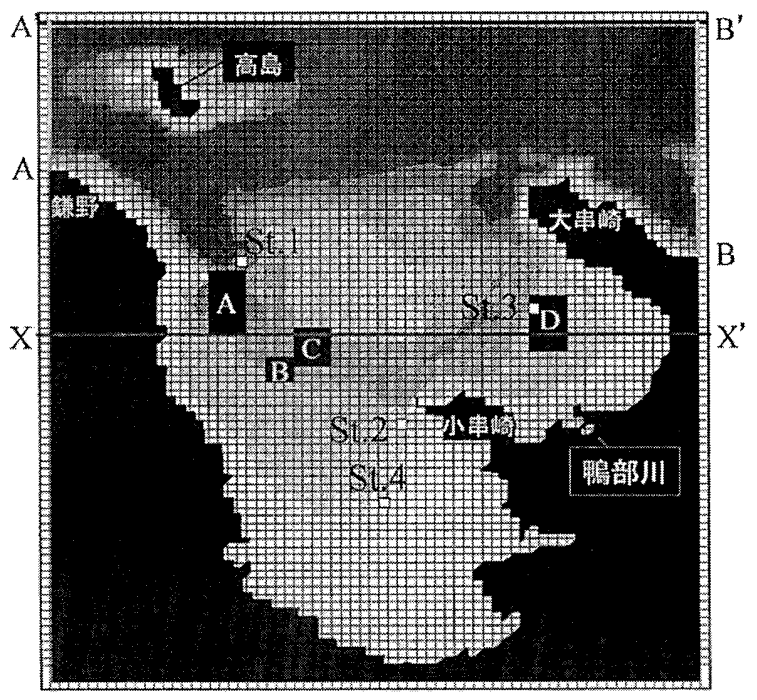

図 3 計算領域 
表 1 計算条件

\begin{tabular}{|c|c|c|}
\hline 緒元 & 単位 & \\
\hline 水平格子間隔 & $\mathrm{m}$ & 100 \\
\hline 鉛直格子間隔 & 層 & 6 \\
\hline 海面・界面摩擦係数 & - & 0.0013 \\
\hline 海底摩擦係数 & - & 0.0026 \\
\hline 水平渦動粘性係数 & $\mathrm{m}^{2} / \mathrm{sec}$ & 100 \\
\hline 水平拡散係数 & $\mathrm{m}^{2} / \mathrm{sec}$ & 1.0 \\
\hline 鈆直拡散係数 & $\mathrm{m}^{2} / \mathrm{sec}$ & 0.001 \\
\hline ユリオリパラメータ & $\mathrm{sec}^{-1}$ & 8.19 \\
\hline 河川流量 (鴨部川) & $\mathrm{m}^{3} / \mathrm{day}$ & $3.9 \times 10^{4}$ \\
\hline \multicolumn{2}{|r|}{} \\
\end{tabular}

表 2 境界条件

\begin{tabular}{|c|c|c|c|}
\hline 開境界 & 潮位振幅 $(\mathrm{m})$ & 周期 (時間) & 遅角 (度) \\
\hline $\mathrm{A}$ & 0.563 & 12.42 & 324.5 \\
\hline $\mathrm{A}^{\prime}$ & 0.563 & 12.42 & 324.5 \\
\hline $\mathrm{B}$ & 0.456 & 12.42 & 331.9 \\
\hline $\mathrm{B}^{\prime}$ & 0.456 & 12.42 & 331.9 \\
\hline
\end{tabular}

\section{3-1. 志度湾の流況}

前述の計算条件および境界条件を踏まえ数值計算を行い, 最終一 潮汐周期間の結果から, 代表として東流最強時と西流最強時を水平 流況べクトル図で表した。なお，結果は全て第 1 表層 $(0 \sim 1.5 \mathrm{~m})$ のものである。

図 4-1 の東流最強時では，既存の研究では再現できていなかった 湾口部西端付近に位置する高島の地形的影響を受けた湾内一の強 い流れの入り込みを再現していることが判る。そして，流れは小串 崎, 大串崎先端付近を経て湾外一流出している。これは「上げ潮, 下げ潮ともに海水が大串崎付近と小串崎付近から流出している」と 報告している過去の志度湾の潮流観測記録と一致している ${ }^{2), 3) 。 ~}$

また，図 4-2の西流最強時でも同様に長浜湾，玉浦湾で流れが弱 く, 湾口で強い流れとなっており，観測記録 ${ }^{2)}$ との精度良い一致を みせている。

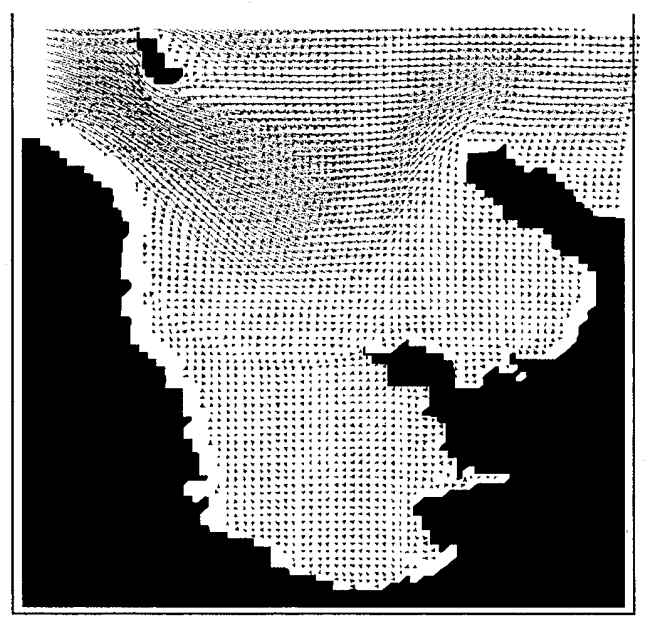

図 4-1 潮流計算結果（東流最強時） $\rightarrow 100 \mathrm{~cm} / \mathrm{sec}$

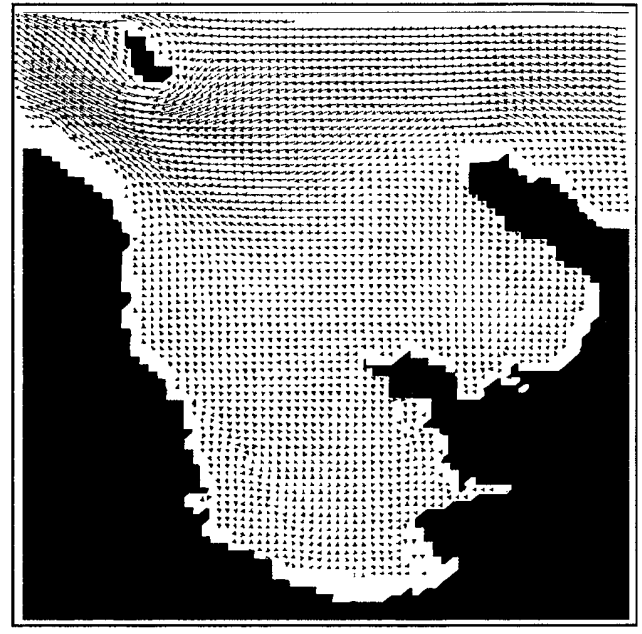

図 4-2 潮流計算結果（西流最強時） $\rightarrow 100 \mathrm{~cm} / \mathrm{sec}$

\section{3-2. 潮流棈円}

前項の流況ベクトル図で, 志度湾の流況に関する計算結果と観測 結果との精度の良い一致を確認した。次に，潮流の計算結果と観測 值を流向・流速という詳細な点で比較，検討するために潮流棈円を 描き，これにより定量的評価を行った。（図 5 参照）

比較する地点は, 図 3 に示した湾口部付近に位置する St.1, 小串 崎付近の St.2, 長浜湾内の St.3の 3 地点である。各地点において湾 口から湾央にかけて流速，長軸の方向ともに計算結果と観測結果は 概文良い一致を見せている。特に St.1 では高島付近の地形的影響に よる流れが再現されたことに基づき，長軸の方向，長さともにほぼ 一致していることが判る。

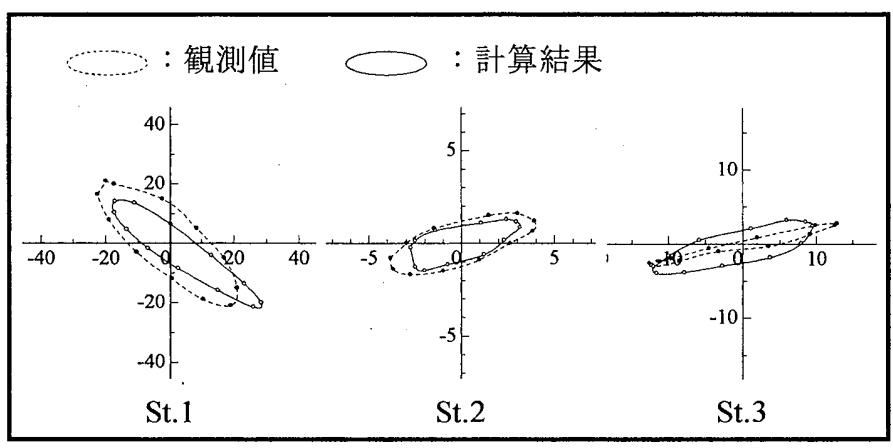

図 5 潮流楕円図

\section{3-3. 潮汐残差流}

志度湾における流況特性の最たる特徽として, 西から東への恒流

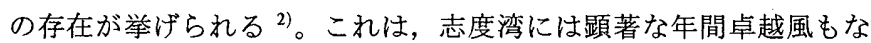
く，大規模な流量をもつ河川もないことから，これによる潮汐残差 流の存在が支配的であると考えられる。そこで，表層 $(0 \sim 1.5 \mathrm{~m})$ における潮汐残差流の計算を行い，計算結果を図 6 に，過去に観測 されている潮汐残差流 ${ }^{2)}$ を図 7 に示す。

両者を比較すると，既存の観測結果から得られている湾口の西側 から入り，小串崎地先を経て反時計回りに東側へ出ていくという傾 向が，精度良く再現出来ていることが判る。

流況ベクトル図，潮流楕円，潮汐残差流に関する評価を総括する 
と，志度湾における流況特性を既存の手法 ${ }^{1)}$, 5) 以上に定量的に再現 できたと考える。

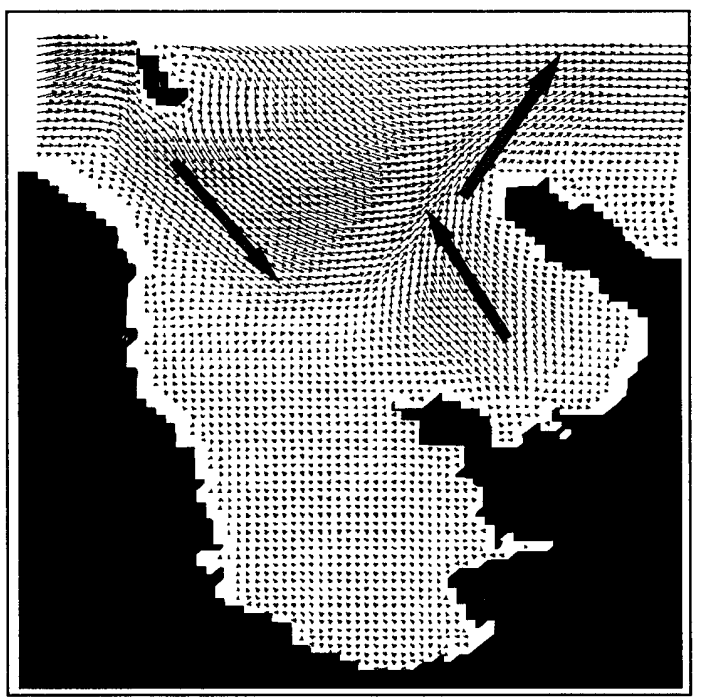

図 6 潮汐残差流（計算結果）

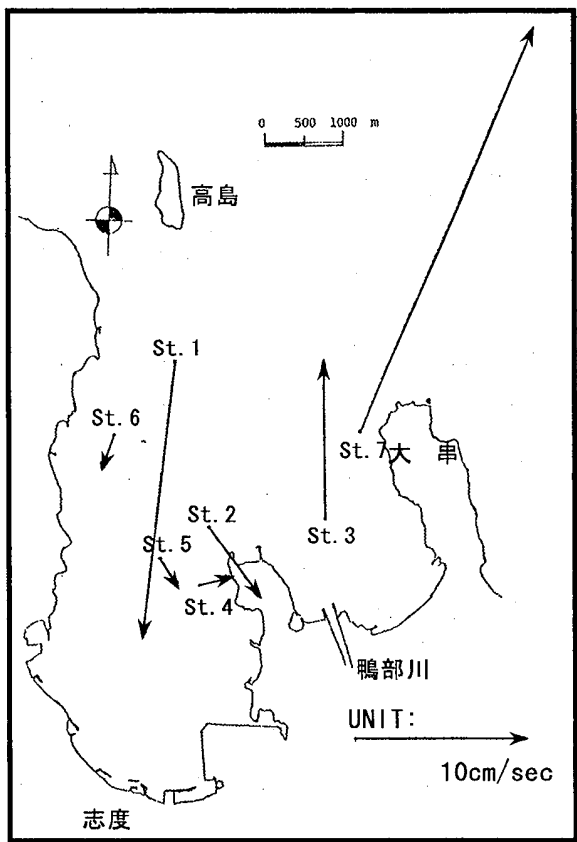

図 7 志度湾の潮汐残差流の観測結果 ${ }^{2)}$

\section{4. 沿岸生態系に関する再現性の評価・検討}

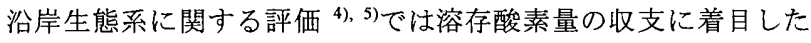
数值シミュレーションを行うが，その際に初期值として与える各パ ラメータの物理量および計算結果と比較する観測值は，現地観測に より得られた 2000 年 8 月のデー夕を使用した。また，研究の新規 的要素として考虑する志度湾の八マチ養殖，その主な養殖エリアは 図 3 の A，B，C，D地点であり，このエリアの表・中層，また，2006 年 8 月に行った底泥による酸素消費速度を初期值として与えて計算 を行った（表 3 参照）。

底泥による酸素消費速度に関しては, 底泥をサンプリングし, サ イホンにより海水をろ過した後, 底泥表面を乱さないように $20^{\circ} \mathrm{C}$ 蒸
留水を注入し, 光の影響を遮断するため暗幕を張り, 恒温槽に設置 して底泥による酸素消費速度を求めた 6 )，7。また，魚類による酸素 消費速度に関しては, $0.5 \mathrm{~m}^{3}$ の飼育水槽に魚体重 $1 \mathrm{~kg}$ 程度のハマチ を投入し, 外部からの空気の浸入を遮断し, 水槽中の溶存酸素量の 変化について 24 時間連続観測を行った。これらにより, $\mathrm{A} \sim \mathrm{D} の$ 各 地点で求めた底泥および魚類による酸素消費速度を数值シミュレ ーションモデルに適用した。

表 3 酸素消費速度

\begin{tabular}{|c|c|c|c|}
\hline 地点 & 単位 & 表層（ハマチ） & 底層（底泥） \\
\hline A：庵治漁協 & \multirow{4}{*}{$\mathrm{ml} / \mathrm{sec} / \mathrm{m}^{2}$} & 0.00292 & 0.0171 \\
\hline B：志度漁協 & & 0.00411 & 0.0176 \\
\hline $\mathrm{C}$ ：牟礼漁協 & & 0.00479 & 0.0177 \\
\hline D：鴨庄漁協 & & 0.00778 & 0.0180 \\
\hline
\end{tabular}

上記の計算条件，また酸素消費速度を用いて数値計算を行い，表 層 $(0 \sim 1.5 \mathrm{~m})$ ） と底層 $(9.0 \mathrm{~m})$ における溶存酸素量の水平分布を図 8 に表した。また，このとき使用している数値モデルの検証も兼ねて， 水産養殖の負荷を考慮したもの（酸素消費速度を扱ったもの）とそ うでないものの二通りを計算し，これらを観測值 ${ }^{2), 3)}$ と比較し，評 価・検討を行った。

まず，表層に関する評価であるが，水産養殖の負荷を考慮してい る計算結果と 2000 年 8 月の観測値を比較してみると, 考慮してい ない計算結果よりも精度良く再現されていることが分かる。特に, 湾奥部で定量的な再現性がとれている他, 陸水からの負荷を分解す る傾向が卓越している鴨部川河口付近で低濃度になるといった実

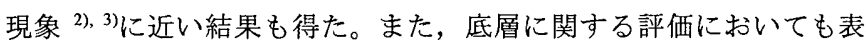
層と同梯のことが言え，水産養殖が展開されている海域周辺では湾 全体的に見ると低濃度であり，底泥による酸素消費が影響している ものと考えられる。

夏季の閉鎖性海域では, 成層が発達し, 貧・無酸素水塊が形成さ れることが少なくない。貧酸素水塊の形成は, 湾内の水質は勿論の こと, 養殖魚場環境も悪化する。本項では湾の特定のエリアを鉛直 方向に見ることにより, 貧酸素水塊を形成する要因となる躍層の有 無を確認し，これを踏まえた評価・検討を行う。今回，評価を行っ たエリアは, 図 3 の St.4 並びにX と X’を結ぶ線で湾を断面化した X-X’ 断面である。St.4 における溶存酸素量の計算結果と観测值を 比較している鉛直分布を図 9 に示す。計算結果と観測值ともに底層 に進むにつれて溶存酸素濃度が減少傾向を辿っているが，いずれも 最も低い数值を示している水深 $5.5 \mathrm{~m}$ 付近で $5.7 \sim 5.9 \mathrm{mg} / 1$ と, 貧酸 素水塊 $(2 \sim 3 \mathrm{mg} / 1$ 以下 $)$ と呼ばれるほど, 低濃度ではないことが分 かる。また，計算結果と観測值を比較してみて判るように，定量的 にもかなり良い精度で再現されていると思われる

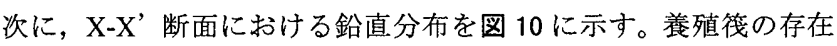
するエリアを断面化したが，養殖エリア $\mathrm{A} ， \mathrm{~B} ， \mathrm{C}$ 付近は流れがあ る程度循環しており，養殖からの負荷が拡散するためか，比較的， 底層まで溶存酸素量が高濃度を維持している。しかし，長浜湾側に 存在する養殖エリア D 付近は, 流れが停滞していると言った要因も 重なり，表層と底層で $1 \mathrm{mg} / 1$ 程の差があることが判る。ただし，図 8 の結果と併せて検討しても判るように, 顕著な躍層, またそれに 


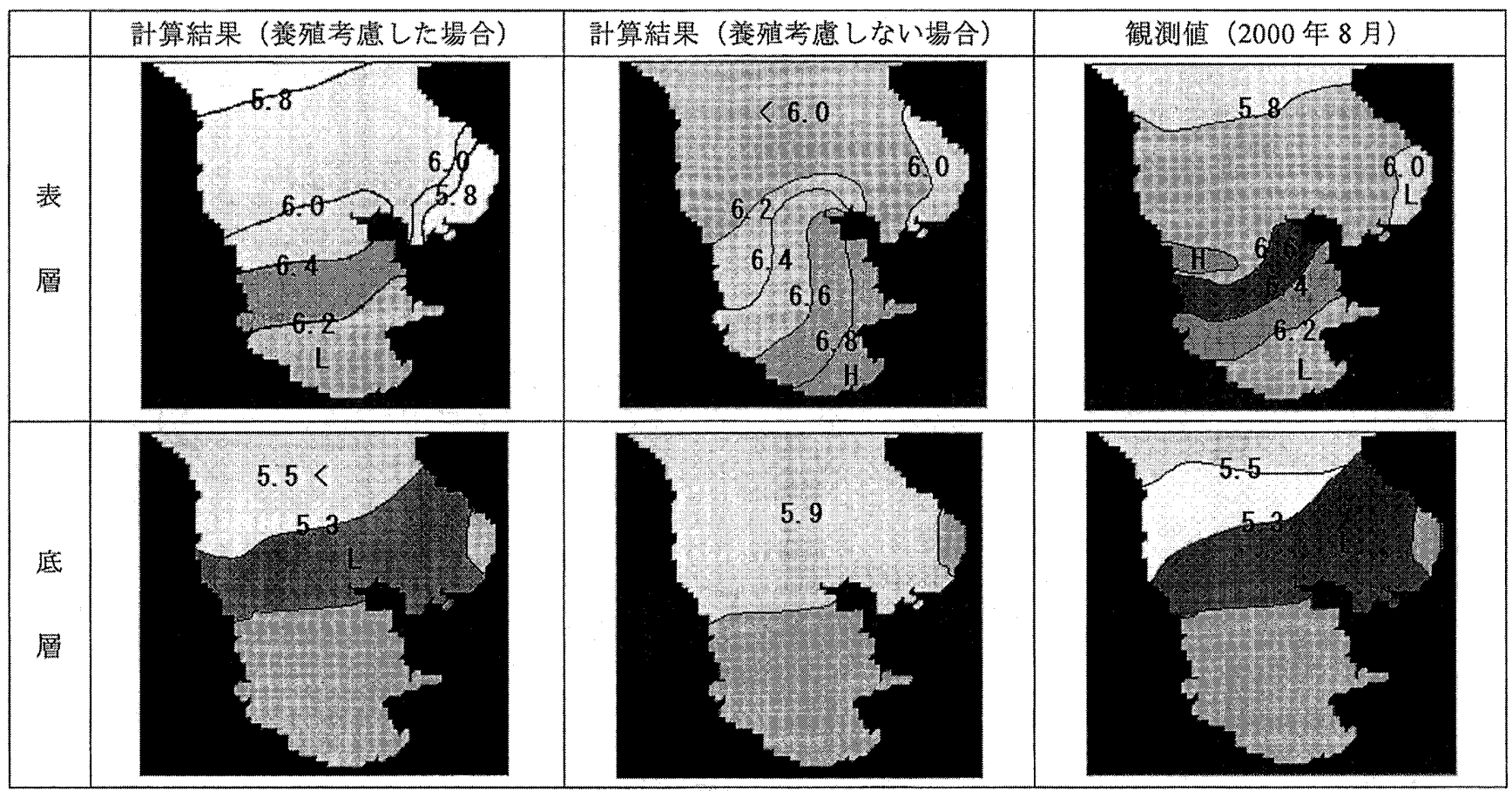

図 8 志度湾の溶存酸素量の水平分布図

$(\mathrm{mg} / \mathrm{l})$

よる貧酸素水塊の形成は本研究の結果から見受けられず，志度湾の 水質および養殖漁場環境が保たれていることが，計算結果からも考 えられる。

村上らは魚介類にとって維持されるべき溶存酸素濃度について, 1）魚介類を死に至らしめる溶存酸素 濃度 $(1 \sim 2 \mathrm{ml} / \mathrm{l})$

2）底生生物の生理，生態的変化に影 響を与える溶存酸素濃度 (2〜 3ml/1)

3）養殖漁場形成に影響を与える溶存 酸素濃度 $(3 \mathrm{ml} / \mathrm{l})$

と報告している。

今回の志度湾における数值シミュ レーションではこれらを満足してお り，生物生息環境の視点からの定量的 評価においても良い結果を示してい ると言える。

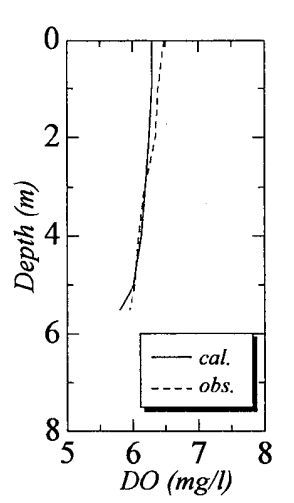

図 $9 \mathrm{DO}$ 鉛直分布 比較（St.4）

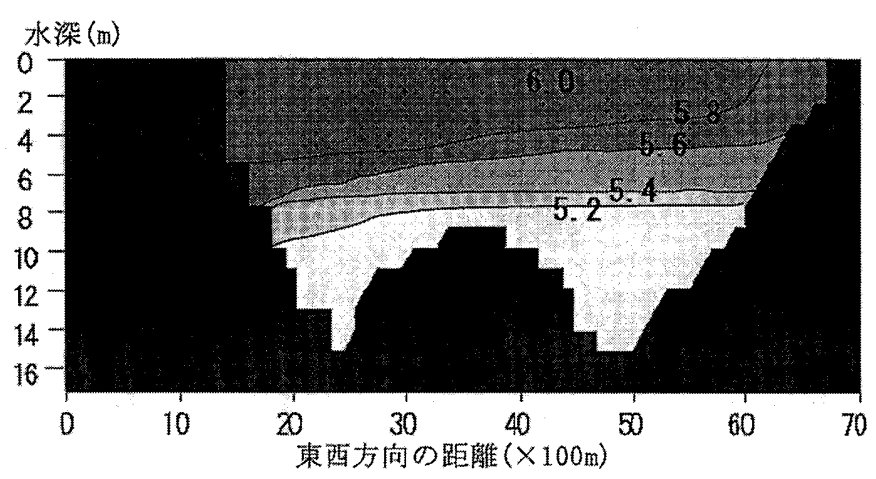

図 10 DO 鉛直分布計算結果 (X-X' 断面) $(\mathrm{mg} / \mathrm{l})$

\section{5. 環境容量の検討}

溶存酸素に関する計算結果に基づき，志度湾における溶存酸素環 境の現状と養殖密度を指標とした環境容量 ${ }^{8)}$, 9)の検討を行った。

実際に養殖が行われており，特に他の地点よりも環境悪化が懸念 される $\mathrm{D}$ 地点について，八マチの収容尾数を変化させた場合と酸素 消費速度の関係を図 11 に示す。図中の消費（鮘類，底泥による消 費）と供給（大気からの溶入，光合成による生成）のグラフが交わ る点が，溶存酸素の収支が均衡している状態である。それより左に 移行すれば溶存酸素環境が好ましい状態であり，逆に右に移行すれ ば環境悪化が進行することが懸念される。

結果から，現状の收容尾数は，やや過㮃状態にあると考えられる。 これを現状の約 $10 \%$ 減の状態が D地点における限界収容尾数にな ることが計算結果より推察された。今後は，魚類の適正収容密度の 検討のみならず，養殖漁場への酸素供給量を増加させるために移流 による酸素供給が期待される場所への養殖筏の移動や酸素消費量 の低減のために養殖筏直下の底質を改善する等，言い換えれば富栄 養化を抑制するための対策を講じる必要がある。

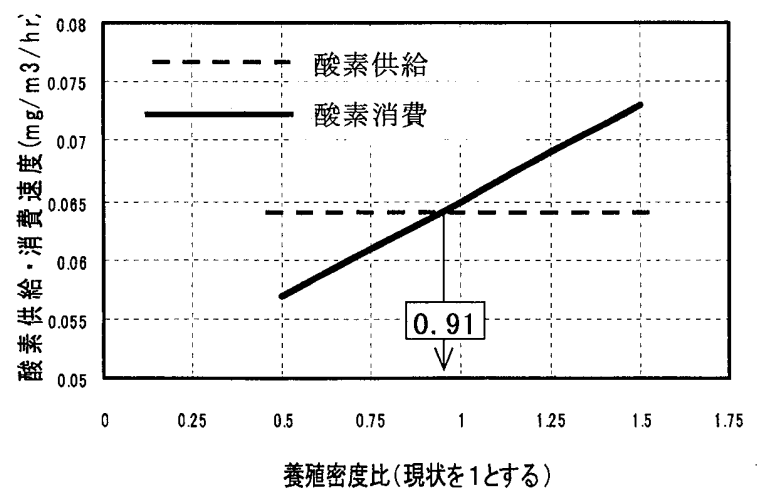

図 11 酸素供給・消費速度と養殖密度の関係 


\section{6. 結言}

1）今回の数值シミュレーションで，志度湾の流況特性である，高 島の存在を主とした地形的影響による恒流成分を再現することが できた。

2）溶存酸素環境の現状と養殖密度を指標とした環境容量の検討を 行った結果, 現状の収容尾数は, やや過㮃状態にあると考えられ, 現状の約 $10 \%$ 減の状態が限界収容尾数になることを指摘した。

3）水産養殖からの負荷，具体的に養殖魚類及び底泥の酸素消費速 度を数值シミュレーションで扱ったことで，より定量的且つ定性的 な評価が行え, 厳密な志度湾の海域特性の再現を可能とした。

今後，閉鎖性海域において生物を利用したレジャー施設等の海域 構造物が設置される際，本技術を有効活用することにより，海域環 境への影響を定量的に予測することが可能となる。

\section{参考文献}

1）田中和広，富澤伸樹：「赤潮発生海域における環境影響評価に関する研究」 日本建築学会学術講演梗概集 A-2 分冊, pp.299-300, 1999
2) 大川西部公共下水道浄化センター放流水の水産業への影響に関する調査研 究会 : 大川西部公共下水道浄化センター放流水の水産業への影響に関する 調查報告書, pp.1-23, 1982

3）前田義洋：閉鎖性海域における水産養殖の影響評価, 香川大学大学院農学 研究科, 修士論文, pp1-36, 2003

4）岸道郎：「底泥による酸素消費を考虑した養殖場数值モデル」沿岸海洋研 究ノート第 32 巻第 1 号, pp.43-53, 1994

5）藤原正幸, 河地利彦 : 低次生産生態系モデルの感度解析, 農業土木学会, 応用水理研究部会第 2 回研究集会講演集, pp.17-26, 1994

6）平野敏行 監修：沿岸の環境圈，フジテクノシステム, pp.561-646, 1998

7）香川県水産試験場：赤潮対策技術開発試験報告書, pp.5-12, 1987

8) 末永慶寛, 河原能久, 山本直樹, 田中陽二: 海域生物環境改善技術の開発, 土木学会論文集, No.755/Vii-30, pp.29-36, 2004

9）小林哲朗：播磨灘引田湾の漁場環境容量評価システム, 香川大学大学院工 研究科, 修士論文, pp36-50, 2003

(2006年11月 10 日原稿受理，2007年 4 月26日採用決定） 